\title{
Mitigation of Salt Stress in Lettuce (Lactuca sativa L. var. Crispa) by Seed and Foliar 24-epibrassinolide Treatments
}

\author{
Melek Ekinci ${ }^{1}$, Ertan Yildirim, and Atilla Dursun \\ Atatürk University, Faculty of Agriculture, Department of Horticulture, \\ 25240 Erzurum, Turkey

\section{Metin Turan \\ Atatürk University, Faculty of Agriculture, Department of Soil Science, 25240 Erzurum, Turkey}

Additional index words. lettuce, salt stress, 24-EBL, growth, chlorophyll, mineral content

\begin{abstract}
The objective of this study was to determine the effect of 24-epibrassinolide (24-EBL) applications on growth, chlorophyll, and mineral content of lettuce (Lactuca sativa $\mathrm{L}$. var. Crispa) grown under salt stress. The study was conducted in pot experiments under greenhouse conditions. Lettuce seedlings were treated with seed and foliar 24-EBL applications at different concentrations $(0,1,2$, and $3 \mu M)$. Salinity treatments were established by adding 0,50 , and $100 \mathrm{~mm}$ of sodium chloride $(\mathrm{NaCl})$ to a base complete nutrient solution. Results showed that salt stress negatively affected the growth and mineral content of lettuce plants. However, seed and foliar applications of 24-EBL resulted in greater shoot fresh weight, shoot dry weight, root fresh weight, and root dry weight as well as higher stem diameter than the control under salt stress. Salinity treatments induced significant increases in electrolyte leakage of plant, but foliar 24-EBL application reduced leaf electrolyte leakage and has determined lower values of leaf electrolyte leakage than non-treated ones. In regard to nutrient content, it can be inferred that 24-EBL applications increased almost all nutrient content in leaves and roots of lettuce plants under salt stress. Generally, the greatest values were obtained from $3 \mu M$ 24-EBL application. Treatments of 24-EBL alleviated the negative effect of salinity on the growth of lettuce.
\end{abstract}

Salinity is one of the most serious abiotic stress factors limiting crop productivity. Worldwide, 100 million ha or $5 \%$ of the arable land is adversely affected by high salt concentrations reducing crop growth and yield (Ghassemi et al., 1995). In Turkey, $\approx 2$ million ha of cultivated land is affected by salinity and alkalinity (Gungor and Erezol, 1994). Salt stress affects plant physiology, both at whole plant as well as cellular levels, through osmotic and ionic stress. High salt concentrations are toxic to seed germination, seedling growth, vegetative growth, flowering and fruit set, and ultimately diminish economic yield and quality of produce (Arora et al., 2008). Vegetable crops are generally more salt-sensitive than grains and forages (Shannon, 1997). Lettuce is considered to be a relatively salt-sensitive vegetable (Barassi et al., 2006). Salinity has been shown to reduce seed germination, fresh and dry weight of shoot, and root weight of lettuce both by ionic and osmotic effects (Barassi et al., 2006; Tarakcioglu and Inal, 2002).

Received for publication 22 Dec. 2011. Accepted for publication 7 Mar. 2012.

We thank Ataturk University for generous financial support (Project No. 2010/259).

${ }^{1}$ To whom reprint requests should be addressed; e-mail ekincim@atauni.edu.tr.
Various strategies have been used to maximize plant growth and productivity under environmental stresses such as salt stress. A fundamental approach is to develop salttolerant plants through genetic means. Breeding for salt tolerance, however, is a long-term endeavor with its own complexities and inherent difficulties. The success of this approach depends, among others, on the availability of genetic sources of tolerance and reliable screening techniques, identification and successful transfer of genetic components of tolerance to desired genetic backgrounds, and development of elite breeding lines and cultivars with salt tolerance and other desirable agricultural characteristics. Such extensive processes have delayed development of successful salt-tolerant cultivars in most crop species. An alternative and technically simpler approach is to induce salt tolerance through exogenous application of certain plant growth-regulating compounds. Although several mechanical, chemical, and biological approaches are being pursued to overcome the menace of soil salinity, exogenous application of plant growth regulators including cytokines and gibberellins (Amzallag et al., 1992) and even brassinosteroids (Vardhini and Rao, 1997) is considered to be effective in alleviating the adverse effects of salinity stress. Among these, brassinosteroids (BRs) have been the main focus of much research in the last 10-20 years. BRs have been reported to affect plant growth and development in many different ways and are known to improve plant stress tolerance (Ashraf et al., 2010).

BRs are a new group of plant growth substances that promote plant growth and productivity. Like other plant hormones, BRs affect many physiological processes such as cell expansion, cell division, xylem differentiation, proton pump activity, ethylene biosynthesis, and photosynthesis (Xia et al., 2009). Brassinosteroids also confer resistance to plants against various abiotic stress including salt stress (Anuradha and Rao, 2001; Ashraf et al., 2010). However, the effect of 24-EBL on growth, physiology, and nutrient uptake on lettuce under salt stress conditions has yet not been well studied. Therefore, this experiment focuses on the effect of the exogenous application of 24-EBL as a foliar spray and seed treatment on the plant growth, some physiological variables, and chemical content of lettuce plants under saline conditions.

\section{Materials and Methods}

Growth conditions and plant materials. The study was conducted in Erzurum (lat. $40^{\circ} 31^{\prime} \mathrm{N}$; long. $40^{\circ} 54^{\prime} \mathrm{E}$ ), Turkey, in 2010 , under greenhouse conditions. Lettuce (cv. Kivircik marul 055) plants were maintained under natural light conditions, approximate day/night temperatures of $27 / 14^{\circ} \mathrm{C}$, and $75 \%$ relative humidity during the span of the experiment. Lettuce seeds were sown into plastic trays filled with peat. Thirty days after planting (DAP), seedlings were transplanted to pots (80 and $20 \mathrm{~cm}$ length and width, respectively, and $25 \mathrm{~cm}$ height with holes in the bottom) filled with mixture of peat:perlite $(1: 1, \mathrm{v}: \mathrm{v})$. Each pot had four plants. Pots were placed randomly on the benches in the greenhouse.

Treatments of 24-epibrassinolide. Treatments of 24-EBL were made together with seed and foliar application. Treatments of 24EBL $\left(\mathrm{C}_{28} \mathrm{H}_{48} \mathrm{O}_{6}\right.$, molecular weight $=480$; Sigma) was initially dissolved in ethanol and concentrations of $0,1,2$, and $3 \mu \mathrm{M}$ were made up with distilled water containing $0.02 \%$ Tween 20 (polyoxyethylenesorbitan monolaurate; Sigma Chemicals, U.K.) as a surfactant. For seed treatments, seeds were soaked in the 24EBL suspensions amended with Tween 20 to facilitate the adherence to the seeds and incubated at room conditions for $24 \mathrm{~h}$. After incubation, the seeds were air-dried before use. Seeds were soaked in distilled water amended with Tween 20 and served as the control. Solutions of 24-EBL were applied to the seed-treated plants during late afternoon using a handheld sprayer the day after transplanting to pots. To avoid interferences with different moisture levels, a control spray treatment consisting of $0.02 \%$ Tween 20 in distilled water was applied to those treatments not receiving $24-E B L$ at a given time. The lower leaf surface was sprayed until wet as well as the upper surface because it was reported that absorption by the lower leaf surface was rapid and effective (Hull et al., 1975). At 10 DAP, plants were again treated with distilled water or one of the solutions of $0,1,2$, and $3 \mu \mathrm{M}$ 
24-EBL. Plants from each treatment were sprayed with $100 \mathrm{~mL}$ of each solution.

Salt treatments. Salt treatments were established by adding 0,50 , and $100 \mathrm{~mm}$ of $\mathrm{NaCl}$ to a base complete nutrient solution (SoFertig) when the plants were transplanted. The composition of the SoFertig (Elfatochem Co., Paris, France) was 2.38 nitrogen (N), 5.58 phosphorus (P), 24.18 potassium $(\mathrm{K}), 0.48$ magnesium $(\mathrm{Mg}), 3.84 \mathrm{SO}_{4}, 0.0023$ sodium $(\mathrm{Na}), 0.112$ iron $(\mathrm{Fe}), 0.0013$ zinc $(\mathrm{Zn}), 0.0128$ copper $(\mathrm{Cu}), 0.001$ boron (B), 0.0055 manganese (Mn), and $0.0096 \mu \mathrm{M} \cdot \mathrm{L}^{-1}$ molybdenum. The dilute solution $(1 / 10)$ was prepared by adding SoFertig to the distilled water. $\mathrm{NaCl}$ was added to the nutrient solution at ratios of 0 , 50 , or $100 \mathrm{~mm}$. The electrical conductivities of these solutions after adding 0,50 , and $100 \mathrm{~mm}$ of $\mathrm{NaCl}$ were determined with a conductivity meter, Model 470 (Jenway Limited, Essex, U.K.). Electrical conductivities of these solutions were $1.72 \mathrm{dS} \cdot \mathrm{m}^{-1}$ for $0 \mathrm{~mm} \mathrm{NaCl}, 7.76$ $\mathrm{dS} \cdot \mathrm{m}^{-1}$ for $50 \mathrm{~mm} \mathrm{NaCl}$, and $11.71 \mathrm{dS} \cdot \mathrm{m}^{-1}$ for $100 \mathrm{~mm} \mathrm{NaCl}$. All pots were irrigated to field capacity with saline solutions to maintain the level of salinity after transplanting.

Leaf chlorophyll reading value. A portable chlorophyll meter (SPAD-502; Konica Minolta Sensing, Inc., Japan) was used to measure leaf greenness of the plants. A SPAD-502 chlorophyll meter can estimate total chlorophyll amounts in leaves of a variety of species with a high degree of accuracy, which is a non-destructive method (Neufeld et al., 2006). For each plant, measurements were taken at four locations on each leaf, two on each side of the midrib on all fully expanded leaves, and then averaged (Khan et al., 2003).

Membrane permeability. For measurement of membrane permeability (MP), 10 leaf discs (10 $\mathrm{mm}$ in diameter) from the young fully expanded leaves from two plants per replicate were placed in $50-\mathrm{mL}$ glass vials and rinsed with distilled water to remove electrolytes released during leaf disc excision. Vials were then filled with $30 \mathrm{~mL}$ of distilled water and allowed to stand in the dark for $24 \mathrm{~h}$ at room temperature. Electrical conductivity (EC1) of the bathing solution was determined at the end of the incubation period. Vials were heated in a temperature-controlled water bath at $95{ }^{\circ} \mathrm{C}$ for $20 \mathrm{~min}$ and then cooled to room temperature and the (EC2) was again measured. Electrolyte leakage was calculated as a percentage of EC1/ EC2 (Shi et al., 2006).

Stomatal conductance. Stomatal conductance $\left(g_{\mathrm{S}}\right)$ was measured on the youngest fully expanded upper leaf, along the right abaxial side of the leaf lamina, using a porometer ( $\mathrm{Sc}-1$ Porometer; Decagon Devices Inc., WA) at 1000 to $1100 \mathrm{HR}$.

Growth variables. Thirty days after planting, six plants from each replicate were harvested, and stem diameter, shoot fresh and dry weight, and root fresh and dry weight per plant were determined.

Mineral analysis. To determine the mineral concentrations in lettuce leaves from each plot, samples were oven-dried at $68{ }^{\circ} \mathrm{C}$ for $48 \mathrm{~h}$ and ground. The Kjeldahl method and a Vapodest 10 Rapid Kjeldahl Distillation
Unit (Gerhardt, Konigswinter, Germany) were used to determine total N (Bremner, 1996). Macro- [P, sulfur (S), K, calcium $(\mathrm{Ca}), \mathrm{Mg}$, and $\mathrm{Na}$ ] and microelements [ $\mathrm{Fe}, \mathrm{Mn}, \mathrm{Zn}, \mathrm{Cu}$, chlorine $(\mathrm{Cl}), \mathrm{B}$, cadmium $(\mathrm{Cd})$, lead $(\mathrm{Pb})$, aluminum (Al), chromium $(\mathrm{Cr})$, and nickel (Ni)] were determined after wet digestion of dried and ground subsamples using a $\mathrm{HNO}_{3}$ $\mathrm{H}_{2} \mathrm{O}_{2}$ acid mixture $(2: 3 \mathrm{v} / \mathrm{v})$ with three steps in a microwave (Bergof Speedwave Microwave Digestion Equipment MWS-2) (Mertens, 2005a). Tissue $\mathrm{P}, \mathrm{S}, \mathrm{K}, \mathrm{Ca}, \mathrm{Mg}, \mathrm{Na}, \mathrm{Cl}, \mathrm{Fe}, \mathrm{Mn}$, $\mathrm{Zn}, \mathrm{Cu}, \mathrm{B}, \mathrm{Cd}, \mathrm{Pb}, \mathrm{Al}, \mathrm{Cr}$, and $\mathrm{Ni}$ were determined with an inductively coupled plasma spectrophotometer (Optima 2100 DV; PerkinElmer, Shelton, CT) (Mertens, 2005b).

Statistical analysis. The statistical analysis was made using the GLM procedure of SAS (SAS Institute, 1985). The experimental design was hierarchical with respect to two factors arranged in a completely randomized design with three replications. The first factor $(\mathrm{NaCl}$ levels) had three levels $(0,50$, and $100 \mathrm{~mm}$ ), and the second one (24-EBL treatments) had four levels $(0,1,2$, and $3 \mu \mathrm{M})$ (three $\times$ four factorial experimental design). There were three replicates per treatment and eight plants per replicates. Data were subjected to analysis of variance to compare the effects of salt stress treatments and 24-EBL treatments. The differences between the means were compared using the least significant difference test $(P<0.05)$. Regression analysis was also performed on the effect of 24-EBL applications at different concentrations on dry matter in each $\mathrm{NaCl}$ level.

\section{Results}

Salinity stress reduced plant shoot fresh and dry weight, root fresh and dry weight, stem diameter, and $g_{\mathrm{s}}$ but increased MP (Table 1). High salinity $(100 \mathrm{~mm} \mathrm{NaCl})$ increased chlorophyll reading values. Exogenous 24EBL applications partially alleviated deleterious effect of salinity and increased the overall growth of plants as indicated by improvements under both saline and non-saline conditions (Fig. 1). The most effective dose of 24-EBL for alleviating salt stress generally was found to be $3 \mu \mathrm{M}$. Shoot and root dry weights were decreased by $60 \%$ and $65 \%$, respectively, in response to $100 \mathrm{~mm} \mathrm{NaCl}$ compared with the untreated control. There were also no any interactions between $\mathrm{NaCl}$ concentrations and 24-EBL concentrations in regard to shoot fresh and dry weight and root fresh and dry

Table 1. Shoot fresh and dry weight, root fresh and dry weight, stem diameter, chlorophyll reading value, leaf stomatal conductance $\left(g_{\mathrm{S}}\right)$, and membrane permeability of lettuce plants in response to salt stress.

\begin{tabular}{lrrr}
\hline & \multicolumn{3}{c}{$\mathrm{NaCl}$ concentrations } \\
\cline { 2 - 4 } Growth variables & $0 \mathrm{mM}$ & $50 \mathrm{mM}$ & $100 \mathrm{mM}$ \\
\hline Shoot fresh weight (g per plant) & $189.50 \mathrm{a}^{\mathrm{z}}$ & $142.75 \mathrm{~b}$ & $79.25 \mathrm{c}$ \\
Shoot dry weight (g per plant) & $19.50 \mathrm{a}$ & $16.50 \mathrm{~b}$ & $13.75 \mathrm{c}$ \\
Root fresh weight (g per plant) & $57.50 \mathrm{a}$ & $46.50 \mathrm{~b}$ & $38.25 \mathrm{c}$ \\
Root dry weight (g per plant) & $2.95 \mathrm{a}$ & $2.23 \mathrm{~b}$ & $2.07 \mathrm{c}$ \\
Stem diameter $(\mathrm{mm})$ & $25.29 \mathrm{a}$ & $22.04 \mathrm{~b}$ & $18.26 \mathrm{c}$ \\
Chlorophyll reading value & $25.65 \mathrm{~b}$ & $26.07 \mathrm{~b}$ & $31.19 \mathrm{a}$ \\
Leaf $g_{\mathrm{S}}\left(\mathrm{mmol} \cdot \mathrm{m}^{-2} \cdot \mathrm{s}^{-1}\right)$ & $296.25 \mathrm{a}$ & $192.75 \mathrm{~b}$ & $153.00 \mathrm{c}$ \\
Membrane permeability $(\%)$ & $29.41 \mathrm{c}$ & $36.83 \mathrm{~b}$ & $50.00 \mathrm{a}$ \\
\hline
\end{tabular}

${ }^{\mathrm{z}}$ Mean values in lines followed by a different letters differ significantly at $P<0.05$. weight. Furthermore, the most effective 24EBL doses for shoot dry weight were calculated as 2.84 for $0 \mathrm{~mm} \mathrm{NaCl}, 3.2 \mathrm{~mm}$ for 50 $\mathrm{NaCl}$, and 3.77 for $100 \mathrm{NaCl}$ according to regression analysis.

Stem diameter and $g_{\mathrm{s}}$ also were reduced significantly $(P<0.05)$ in salt-stressed plants (Table 1). However, 24-EBL treatments in plants subjected to long-term salt stress partially alleviated these variables. For example, alleviation effects of $3 \mu \mathrm{M} 24-\mathrm{EBL}$ application at $100 \mathrm{~mm} \mathrm{NaCl}$ was $60 \%$ for shoot fresh and dry weight, $50 \%$ for root fresh weight, $27 \%$ for root dry weight, $24 \%$ for leaf chlorophyll reading value (LCRV) and $25 \%$ for stem diameter compared with the untreated control plants (Fig. 1).

The measurements of $g_{\mathrm{S}}$ show how, at salt stress, the plants had strongly decreased $g_{\mathrm{s}}$ values (Table 1). However, exogenous application of 24-EBL plants increased $g_{\mathrm{s}}$ values significantly $(P<0.05)$. The application of $3 \mu \mathrm{M} 24-\mathrm{EBL}$ increased $g_{\mathrm{s}}$ values by $75 \%$ at $100 \mathrm{~mm} \mathrm{NaCl}$ over the control (no 24-EBL treatment) (Fig. 1). MP increased with increasing salt concentration (Table 1). However, 24-EBL applications significantly $(P<0.05)$ decreased MP at 50 and $100 \mathrm{~mm} \mathrm{NaCl}$ (Fig. 1).

The effect of 24-EBL on N, K, Cl, and $\mathrm{Na}$ concentration of root and leaf of lettuce under salt stress is shown in Figure 2. Imposition of salt stress reduced the $\mathrm{N}$ and $\mathrm{K}$ concentration of both leaf and root of lettuce. Especially, 2 and $3 \mu \mathrm{M}$ concentrations of 24-EBL improved these elements contents in both nonstressed and salt-stressed plants of lettuce (Fig. 2). On the other hand, $\mathrm{Na}$ and $\mathrm{Cl}$ concentrations in leaves and roots increased with increasing $\mathrm{NaCl}$ concentration in the nutrient solution, whereas exogenous 24-EBL applications decreased the concentrations of these elements under salt stress (Fig. 2).

Applications of 24-EBL increased the $\mathrm{P}$ and $\mathrm{S}$ concentrations in both shoot and roots of lettuce plants under salt stress. On contrary, Ca concentration in roots of lettuce plants decreased with 24-EBL application under salt stress, whereas $\mathrm{Ca}$ concentration in shoots of lettuce plants increased with 24EBL under salt stress. Application of 24-EBL raised $\mathrm{Mg}$ concentration in both shoot and roots of lettuce plants at $100 \mathrm{~mm} \mathrm{NaCl}$. The highest $\mathrm{Fe}$ and $\mathrm{Mn}$ concentrations in both shoot and roots of lettuce plants were obtained from $3 \mu \mathrm{M}$ 24-EBL applications at high salinity $(100 \mathrm{~mm} \mathrm{NaCl})$. The other mineral elements in both shoot and roots of lettuce plants 

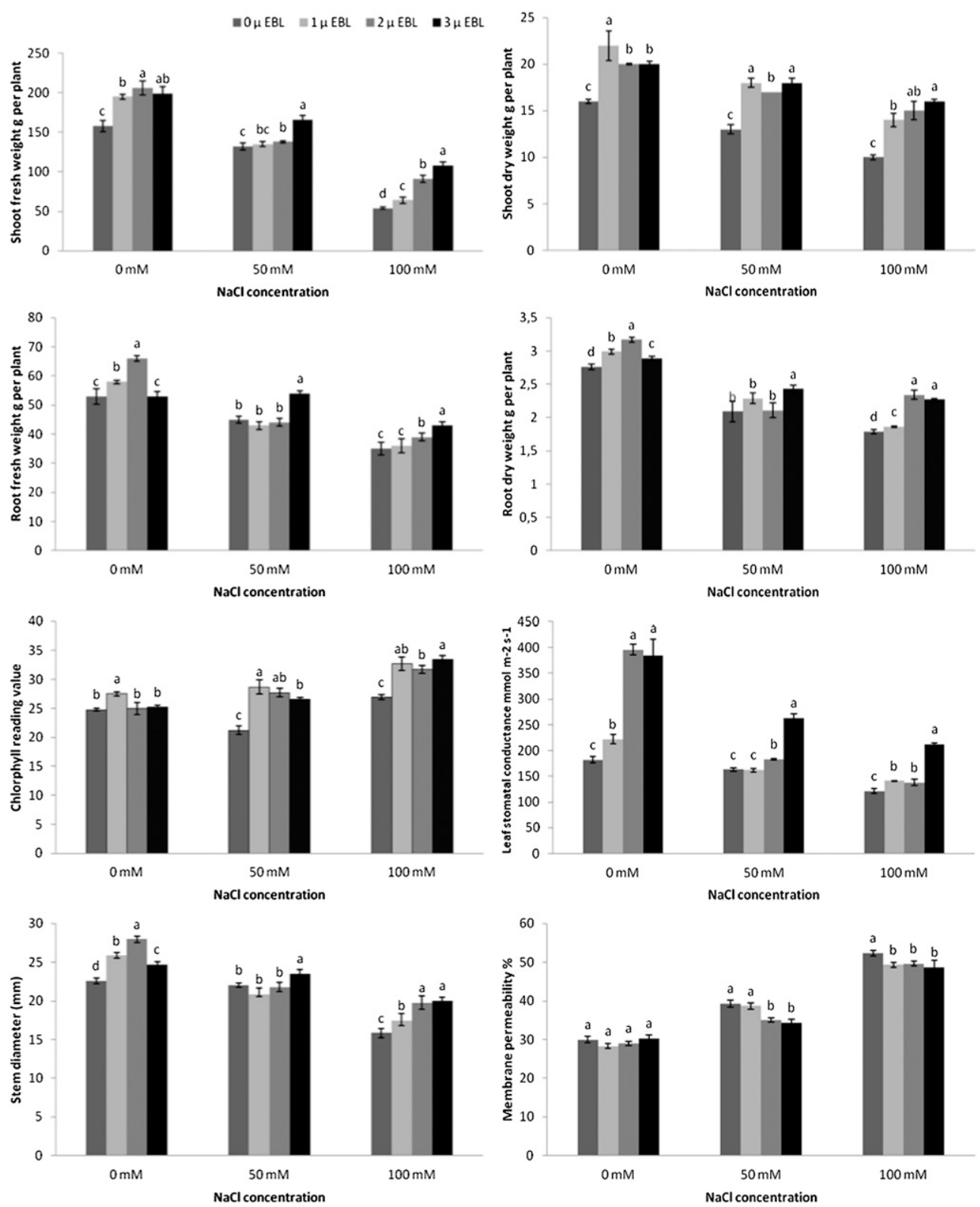

Fig. 1. Mitigating effects of 24-epibrassinolide (24-EBL) on plant shoot and root fresh and dry matter, stomatal conductance, stem diameter, membrane permeability, and chlorophyll reading value of lettuce plants under different salt stress conditions. Different letters on top of bars indicate significant differences according to least significant difference test $(P<5 \%)$. Mean separation within each $\mathrm{NaCl}$ concentration. Vertical bars indicate the mean $\pm \mathrm{SE}, \mathrm{n}=3$.

differently responded to different $\mathrm{NaCl}$ concentrations (Tables 2 and 3). However, mineral element concentrations of plant leaf and root generally increased with increasing 24-EBL doses from 0 to $3 \mu \mathrm{M}$ in given $\mathrm{NaCl}$ concentrations (Tables 2 and 3 ).

\section{Discussion}

Saline soils and saline irrigations constitute a serious production constraint for vegetable crops because saline conditions are known to suppress plant growth (Shannon and Grieve, 1999). The present study demonstrates salinity adversely affected the growth of lettuce like previous studies (Table 1) (Barassi et al., 2006; Tarakcioglu and Inal, 2002). However, 24-EBL treatments offset the negative impact of salinity on growth of lettuce. Treatments of 24-EBL also improved growth variables in the absence of salt stress $(0 \mathrm{~mm} \mathrm{NaCl})$. Previous studies in chickpea (Ali et al., 2007), pepper (Houimli et al., 2008), wheat (Shahbaz et al., 2008), cucumber (Xia et al., 2009), and strawberry (Karlidag et al., 2011) found that foliar application of 24-EBL was effective in increasing plant fresh and dry biomass under both non-saline and saline conditions. BRs can play vital roles in promoting growth and development of plants exposed to saline conditions by modulating a number of metabolic phenomena affecting a plant's tolerance to salt stress (Ashraf et al., 2010). BRs have been shown to affect both cell division and cell enlargement, which play a vital role in growth and development. Stimulation in cell division resulting from BRs has already been observed in cultured parenchyma cells of Helianthus tuberosus (Clouse and Zurek, 1991) and in protoplasts of chinese cabbage
(Brassica campestris ssp. Chinensis) and petunia (Petunia hybrida) (Nakajima et al., 1996; Oh and Clouse, 1998). BRs are known to act along with auxins to stimulate cell elongation (Katsumi, 1991). Furthermore, it has been experimentally proved that BRs could enhance the expression of antioxidant genes and increases the activities of some enzymes including superoxide dismutase, peroxidase, and catalase (Xia et al., 2009). Exogenous application of BRs appears to accelerate seed germination and plant growth and development; however, the extent of their effects may vary with plant species and the concentration applied (Ashraf et al., 2010).

Stomatal conductance values were reduced significantly in leaves of lettuce grown under salt stress (Table 1). The decline in growth in many plant species subjected to a stressful environment is often associated 

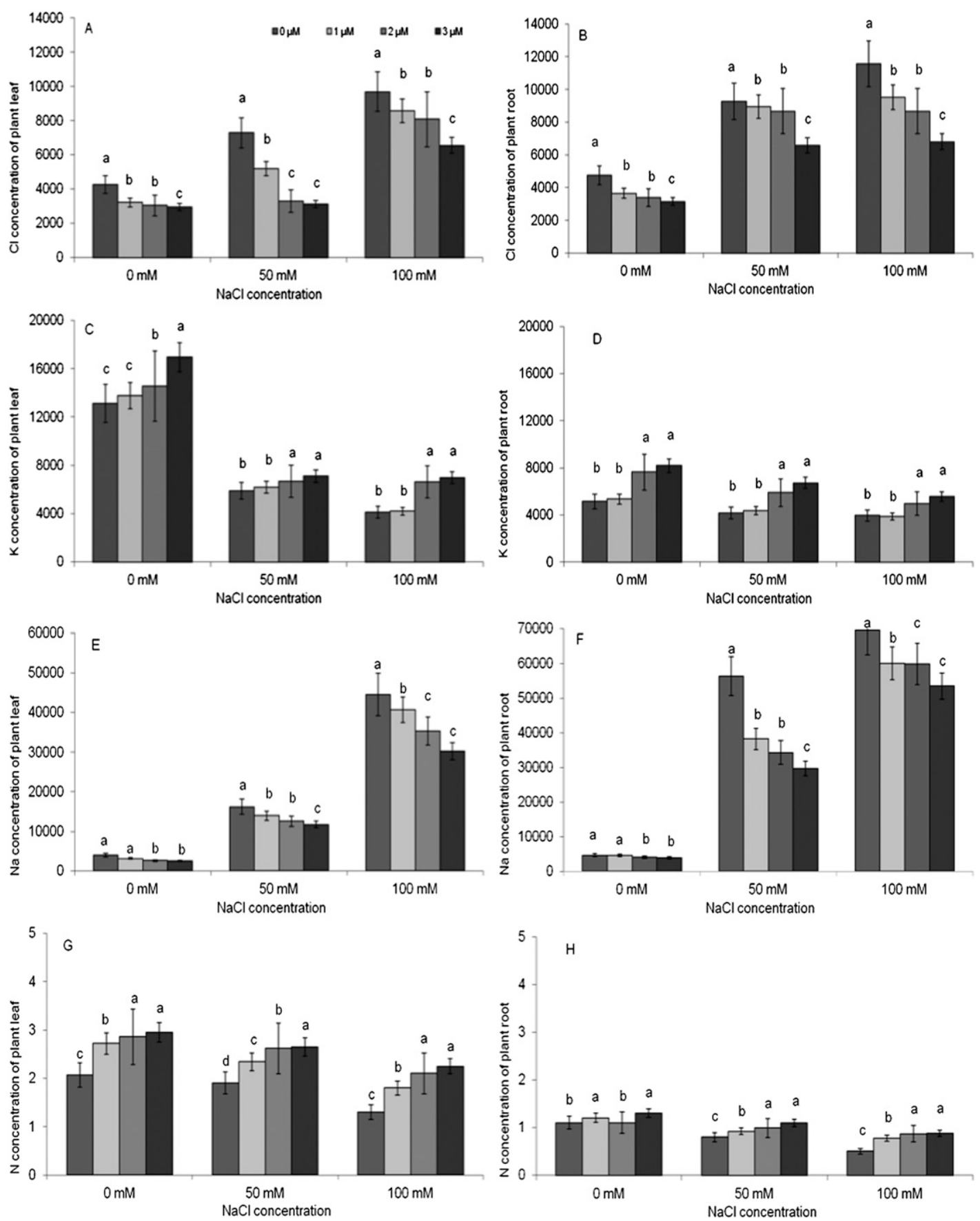

Fig. 2. Effects of 24-epibrassinolide (24-EBL) on plant chlorine (Cl) (A-B), potassium (K) (C-D), sodium (Na) (E-F), and nitrogen (N) (G-H) concentration of lettuce leaf and root under different salt stress conditions. Different letters on top of bars indicate significant differences according to least significant difference test $(P<5 \%)$. Mean separation within each $\mathrm{NaCl}$ concentration. Vertical bars indicate the mean $\pm \mathrm{SE}, \mathrm{n}=3$.

with a reduction in photosynthetic capacity as has been observed in the present study. On the other hand, data suggest that the effect of salt stress on $g_{\mathrm{s}}$ was reduced by the 24-EBL treatments. When 24-EBL was applied exogenously, $g_{\mathrm{s}}$ values increased significantly. These results agree with some earlier results in which BRs improve photosynthetic rate in mustard (Hayat et al., 2000) and mungbean (Fariduddin et al., 2003). Dubey (2005) suggested that the BRs-induced improvement in photosynthetic rate might have been the result of stomatal or non-stomatal factors or a combination of these. Ali et al. (2008) reported that net photosynthetic rate was positively associated with substomatal $\mathrm{CO}_{2}$ and $g_{\mathrm{S}}$, indicating that BR-induced increase in photosynthetic capacity was the result of overcoming stomatal limitations. BRs have also been known to improve water relations increasing relative water content, water use efficiency, $g_{\mathrm{S}}$, and thus the transpiration rate in stressed plants (Ali et al., 2005; Hayat et al., 2010).

Salt stress significantly affected LCRV compared with the non-saline conditions (Table 1). LCRV increased at $100 \mathrm{~mm} \mathrm{NaCl}$. An increase in chlorophyll content (Table 1) has been thought to be the result of the accumulation of $\mathrm{NaCl}$ in the chloroplast (Kirst, 1989). Salt stress has been reported also to induce an increase in the chlorophyll content (Jamil et al., 2007; Misra et al., 1997), which could be the result of an increase in the number of chloroplasts in stressed leaves. On the contrary, salinity has been reported to cause significant reductions in chlorophyll content of cucumber (Yildirim et al., 2008a), radish (Yildirim et al., 2008b), and strawberry (Yildirim et al., 2009). However, 24-EBL treatments increased the LCRV compared with the non-treated plants under salt stress. This positive effect may be the result of BR-induced impact on transcription and/or translation in the synthesis of pigments (Bajguz, 2000). Similarly, Yu et al. (2004) 
Table 2. Effects of 24-EBL on plant nutrient element concentration of root of lettuce under different salt stress conditions. ${ }^{2}$

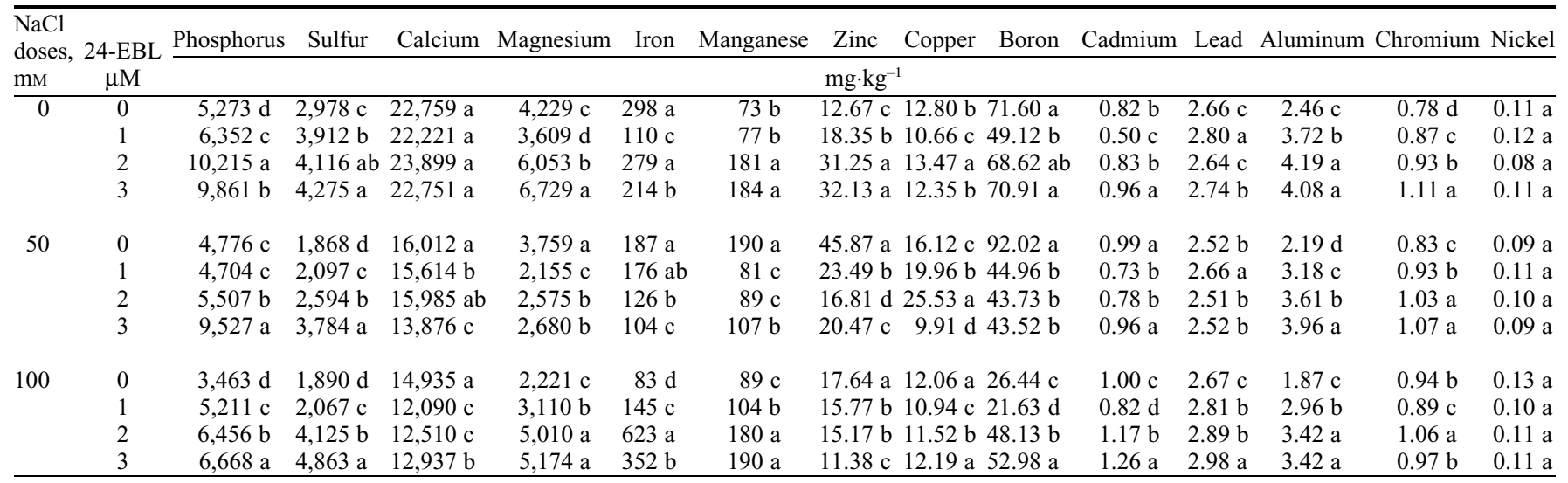

${ }^{\mathrm{z}}$ Means separation within each column by least significant difference test at $P<0.05$.

24-EBL = 24-epibrassinolide.

Table 3. Effects of 24-EBL on plant nutrient element concentration of leaves of lettuce under different salt stress conditions. ${ }^{\mathrm{z}}$

\begin{tabular}{|c|c|c|c|c|c|c|c|c|c|c|c|c|c|c|c|}
\hline $\begin{array}{l}\mathrm{NaCl} \\
\text { doses, } \\
\mathrm{mm}\end{array}$ & $\begin{array}{c}24-\mathrm{EBL} \\
\mu \mathrm{M}\end{array}$ & Phosphorus & Sulfur & Calcium & Magnesium & Iron & Manganese & Zinc & Copper & Boron & Cadmium & Lead & Aluminum & Chromium & Nickel \\
\hline \multirow[t]{3}{*}{0} & 0 & $13,187 \mathrm{~d}$ & $839 \mathrm{c}$ & $7,235 \mathrm{a}$ & $3,825 \mathrm{~b}$ & $225 \mathrm{a}$ & $15 \mathrm{~d}$ & $24.23 \mathrm{~b}$ & $12.67 \mathrm{c}$ & $20.00 \mathrm{~d}$ & $0.38 \mathrm{~b}$ & $2.26 \mathrm{c}$ & $26.45 \mathrm{a}$ & $1.31 \mathrm{~b}$ & $1.29 \mathrm{c}$ \\
\hline & 2 & $18,794 \mathrm{a}$ & $1,579 \mathrm{~b}$ & 8,139 a & $3,268 \mathrm{c}$ & $186 \mathrm{c}$ & $120 \mathrm{a}$ & $0.66 \mathrm{c}$ & $14.28 \mathrm{~b}$ & $22.03 \mathrm{c}$ & $0.41 \mathrm{ab}$ & $2.32 \mathrm{~b}$ & $19.62 \mathrm{~b}$ & $1.61 \mathrm{a}$ & $1.57 \mathrm{~b}$ \\
\hline & 3 & $18,613 \mathrm{~b}$ & $1,913 \mathrm{a}$ & $8,583 \mathrm{a}$ & $4,265 \mathrm{a}$ & $209 \mathrm{~b}$ & $85 \mathrm{~b}$ & $49.41 \mathrm{a}$ & $17.83 \mathrm{a}$ & $29.49 \mathrm{a}$ & $0.48 \mathrm{a}$ & $2.78 \mathrm{a}$ & $16.51 \mathrm{c}$ & $1.67 \mathrm{a}$ & $2.17 \mathrm{a}$ \\
\hline \multirow[t]{2}{*}{50} & 0 & $44 \mathrm{~d}$ & $1,525 \mathrm{~d}$ & $6,842 \mathrm{~d}$ & $3,960 \mathrm{~b}$ & $277 \mathrm{a}$ & $136 \mathrm{c}$ & $.02 \mathrm{c}$ & $23.91 \mathrm{~b}$ & $33.42 \mathrm{~b}$ & $0.84 \mathrm{~b}$ & $2.97 \mathrm{c}$ & $0 \mathrm{a}$ & $2.52 \mathrm{a}$ & $1.63 \mathrm{a}$ \\
\hline & 3 & 13,776 a & $2,755 \mathrm{~b}$ & $8,091 \mathrm{c}$ & $2,973 \mathrm{~d}$ & $172 \mathrm{~d}$ & $157 \mathrm{~b}$ & $23.78 \mathrm{~d}$ & $15.26 \mathrm{c}$ & $27.57 \mathrm{c}$ & $0.48 \mathrm{~d}$ & $2.14 \mathrm{~d}$ & $12.92 \mathrm{c}$ & $1.90 \mathrm{c}$ & $0.74 \mathrm{~d}$ \\
\hline \multirow[t]{4}{*}{100} & 0 & & 2 & & & $164 \mathrm{~d}$ & $103 \mathrm{a}$ & & & & & & & $7 \mathrm{~b}$ & $0.82 \mathrm{c}$ \\
\hline & 1 & $4 b$ & $11 \mathrm{c}$ & $42 \mathrm{~b}$ & $7 \mathrm{a}$ & $334 \mathrm{~b}$ & $75 \mathrm{c}$ & $12.59 \mathrm{c}$ & $18.61 \mathrm{~b}$ & $40.79 \mathrm{c}$ & $1.35 \mathrm{c}$ & $2.08 \mathrm{~d}$ & $5 \mathrm{~b}$ & 6 a & $1.55 \mathrm{a}$ \\
\hline & 2 & $7,395 \mathrm{~b}$ & $2,985 \mathrm{~b}$ & $7,233 \mathrm{ab}$ & $3,131 \mathrm{~b}$ & $238 \mathrm{c}$ & $88 \mathrm{~b}$ & $16.15 \mathrm{~b}$ & $18.88 \mathrm{~b}$ & $61.03 \mathrm{a}$ & $1.41 \mathrm{~b}$ & $2.34 \mathrm{~b}$ & $18.38 \mathrm{c}$ & $1.41 \mathrm{~b}$ & $1.09 \mathrm{~b}$ \\
\hline & 3 & $9,004 \mathrm{a}$ & $3,440 \mathrm{a}$ & $7,370 \mathrm{a}$ & $3,254 \mathrm{a}$ & $460 \mathrm{a}$ & $105 \mathrm{a}$ & $12.77 \mathrm{c}$ & $20.35 \mathrm{a}$ & $40.58 \mathrm{c}$ & $1.59 \mathrm{a}$ & $4.28 \mathrm{a}$ & $37.50 \mathrm{a}$ & $1.89 \mathrm{a}$ & $1.58 \mathrm{a}$ \\
\hline
\end{tabular}

${ }^{\mathrm{z}}$ Means separation within each column by least significant difference test at $P<0.05$.

24-EBL $=24$-epibrassinolide.

showed that a spray of $24-\mathrm{EBL}$ at $0.1 \mathrm{mg} \cdot \mathrm{L}^{-1}$ on cucumber plants led to an increase in the chlorophyll fluorescence. Houimli et al. (2008) determined that foliar application of 24-EBL to pepper (Capsicum annuum L.) plants grown under salt stress significantly reduced the inhibitory effects of salt on shoot growth and leaf relative water content and had a nonsignificant positive effect on root growth and chlorophyll fluorescence. Treatments of 24-EBL $\left(0.1 \mathrm{mg} \cdot \mathrm{L}^{-1}\right)$ could ameliorate the decrease in chlorophyll fluorescence caused by aluminum stress (Dong et al., 2008), chilling stress (Huang, 2005), and weak light stress (Wang et al., 2010). Swamy and Rao (2009) showed that exogenous application of 24-EBL increased the rate of photosynthesis and that growth promotion was associated with increased chlorophyll content in geranium ( $\mathrm{Pel}$ argonium graveolens).

For the present experiment, a tendency toward elevated MP in leaves of salinized lettuce plants was detectable (Table 1). Similar reports were presented by Parida and Das (2005) and Yildirim et al. (2008a, 2008b) for several crops. Parida and Das (2005) reported that salt stress led to a significant increase in the level of electrolyte leakage in many crops. Treatments of 24-EBL lowered the electrolyte leakage in salt-stressed lettuce plants (Fig. 1).
These results are concordant with those of Karlidag et al. (2011) who determined that 24-EBL facilitated the maintenance of membrane functions. This facilitation could be attributed to the induction of antioxidant responses and elevated $\mathrm{Ca}$ uptake that protects the plant from the oxidative damage. Moreover, BRs are reported to modify the membrane structure and stability under stress conditions (Hamada, 1986).

Mineral contents of the leaves and roots of the lettuce plants except $\mathrm{Na}$ and $\mathrm{Cl}$ drastically decreased under salt stress (Fig. 2; Tables 2 and 3). Salinity dominated by $\mathrm{Na}$ and $\mathrm{Cl}$ ions decreased the concentration of essential macroand microelements in several vegetable crops (Grattan and Grieve, 1999; Yildirim et al., 2006). High concentrations of $\mathrm{NaCl}$ in the soil solution may disorder nutrient-ion activities, causing plants to be susceptible to osmotic and specific ion injury as well as to nutritional disorders that result in reduced yield and quality (Grattan and Grieve, 1999). Salt stress increased the $\mathrm{Na}$ and $\mathrm{Cl}$ content in both organs of lettuce plants (Fig. 2).

Treatments of 24-EBL reduced the $\mathrm{Na}$ and $\mathrm{Cl}$ uptake of plants and/or increased the uptake of $\mathrm{N}, \mathrm{P}, \mathrm{K}, \mathrm{Ca}, \mathrm{Mg}$, and the other minerals as compared with control treatment under salt stress (Fig. 2; Tables 2 and 3). Foliar spray with $0.0125 \mathrm{mg} \cdot \mathrm{L}^{-1} \mathrm{EBL}$ increased $\mathrm{K} / \mathrm{Na}$ ratio in salinized plants of $\mathrm{MH}-97$ wheat plants (Shahbaz and Ashraf, 2007). Similarly, seed and foliar treatments of 24-EBL inhibited $\mathrm{Na}$ and $\mathrm{Cl}$ accumulation but stimulated $\mathrm{N}, \mathrm{P}, \mathrm{K}$, $\mathrm{Mg}, \mathrm{Fe}, \mathrm{Mn}$, and other elements' uptake under salt stress. An increase in concentration of $\mathrm{K}$ and $\mathrm{Ca}$ in plants under salt stress could ameliorate the deleterious effects of salinity on growth and yield (Grattan and Grieve, 1999). Alteration of mineral uptake from 24EBL applications may be one mechanism for the alleviation of salt stress. EBL-induced increase in growth was accompanied by a corresponding increase in $\mathrm{K} / \mathrm{Na}$ ratio in the saltstressed plants. A growth-promotive effect of BRs might have also been the result of its role in ion homeostasis, which is necessary for various biochemical or physiological processes controlling growth. For example, BRs has a role in turgor-driven cell expansion by enhancing activity of aquaporins (Morillon et al., 2001) or in proton pumping and modulation of stress tolerance (Sakurai et al., 1999).

As a result, the present study demonstrates salinity stress induced lower plant growth, $g_{\mathrm{s}}$, LCRV, and macro- and microelement content of plant. Treatments of 24-EBL partially ameliorated the deleterious effects of salinity stress on plant growth and improved cell 
membrane stability and nutrient uptake of lettuce under salinity stress.

\section{Literature Cited}

Ali, B., S.A. Hasan, S. Hayat, Q. Hayat, S. Yadav, Q. Fariduddin, and A. Ahmad. 2008. A role for brassinosteroids in the amelioration of aluminium stress through antioxidant system in mung bean (Vigna radiata L. Wilczek). Environ. Exp. Bot. 62:153-159.

Ali, B., S. Hayat, and A. Ahmad. 2007. 28Homobrassinolide ameliorate the saline stress in chickpea (Cicer arietinum L.). Environ. Exp. Bot. 59:217-223.

Ali, M.B., E.J. Hahn, and K.Y. Paek. 2005. Effect of temperature on the oxidative stress defence system, lipid peroxidation and lipoxygenase system in Phalaenopsis. Plant Physiol. Biochem. 43:213-223.

Amzallag, G.N., H. Lerner, and A. Poljakoff-Mayber. 1992. Interaction between mineral nutrients, cytokinins and gibberellic acid during growth of sorghum at higher $\mathrm{NaCl}$ salinity. J. Expt. Bot. 43:81-87.

Anuradha, S. and S.S.R. Rao. 2001. Effect of brassinosteroids on salinity stress induced inhibition of germination and seedling growth of rice (Oryza sativa L.). Plant Growth Regulat. 33:151-153.

Arora, N., R. Bhardwaj, P. Sharma, and H.K. Arora. 2008. Effects of 28-homobrassinolide on growth, lipid peroxidation and antioxidative enzyme activities in seedlings of Zea mays L. under salinity stress. Acta Physiol. Plant. 30:833839.

Ashraf, M., N.A. Akram, R.N. Arteca, and M.R. Foolad. 2010. The physiological, biochemical and molecular roles of brassinosteroids and salicylic acid in plant processes and salt tolerance. Crit. Rev. Plant Sci. 29:162-190.

Bajguz, A. 2000. Effect of brassinosteroids on nucleic acid and protein content in cultured cell of Chlorella vulgaris. Plant Physiol. Biochem. 38:209-215.

Barassi, C.A., G. Ayrault, C.M. Creus, R.J. Sueldo, and M.T. Sobrero. 2006. Seed inoculation with Azospirillum mitigates $\mathrm{NaCl}$ effects on lettuce. Sci. Hort. 109:8-14.

Bremner, J.M. 1996. Nitrogen-total, p. 1085-1122. In: Sparks, D.L. (ed.). Methods of soil analysis, Part III, chemical methods. 2nd Ed. Agronomy, No. 5, Madison, WI.

Clouse, S.D. and D. Zurek. 1991. Molecular analysis of brassinolide action in plant growth and development, p. 122-140. In: Cutler, H.G., T. Yokota, and G. Adam (eds.). Brassinosteroids: Chemistry, bioactivity and applications. Amer. Chem. Soc. Washington D.C.

Dong, D.F., Y.R. Li, and L.G. Jiang. 2008. Effects of brassinosteroid on photosynthetic characteristics in soybean under aluminum stress. Acta Agron. Sin. 34:1673-1678.

Dubey, R.S. 2005. Photosynthesis in plants under stressful conditions, p. 717-718. In: Pessarakli, M. (ed.). Handbook photosynthesis. 2nd Ed. CRC Press, New York, NY.

Fariduddin, Q., A. Ahmad, and S. Hayat. 2003. Photosynthetic response of vigna radiata to presowing seed treatment with 28-homobrassinolide. Photosynthetica 41:307-310.

Ghassemi, F., A.J. Jakeman, and H.A. Nixi. 1995. Salinization of land water resources. CAB International, Wallingford, UK.

Grattan, S.R. and C.M. Grieve. 1999. Salinitymineral nutrient relations in horticultural crops. Sci. Hort. 78:127-157.

Gungor, Y. and Z. Erezol. 1994. Drenaj ve Arazi Islahi. Ders Kitabi. Ankara University, Ankara, Turkey.
Hamada, K. 1986. Brassinolide in crop production, $\mathrm{p}$. 190-196. In: Maegregor, P. (ed.). Plant growth regulators in agriculture. Food Fertilization Technology Central Asia Pacific Region, Taiwan.

Hayat, S., A. Ahmad, M. Mobin, A. Hussain, and Q. Faridduddin. 2000. Photosynthetic rate, growth and yield of mustard plants sprayed with 28-homobrassinolide. Photosynthetica 38: 469-471.

Hayat, S., S.A. Hasan, M. Yusufa, Q. Hayat, and A. Ahmad. 2010. Effect of 28-homobrassinolide on photosynthesis, fluorescence and antioxidant system in the presence or absence of salinity and temperature in Vigna radiata. Environ. Exp. Bot. 69:105-112.

Houimli, S.I.M., M. Denden, and S.B. El-Hadj 2008. Induction of salt tolerance in pepper (Capsicum annuum) by 24-epibrassinolide. EurAsia. J. Biosci. 2:83-90.

Huang, L.F. 2005. The roles for brassinosteroids in the regulation of photosynthesis and antioxidant system in Cucumis sativus $\mathrm{L}$. $\mathrm{PhD}$ thesis, Zhejiang University, May 2005.

Hull, H.M., H.L. Morton, and J.R. Wharrie. 1975. Environmental influence on cuticle development and resultant foliar penetration. Bot. Rev. 41:421-451.

Jamil, M., S. Rehman, and E.E. Rha. 2007. Salinity effect on plant growth, Psis photochemistry and chlorophyll content in sugar beet (Beta vulgaris L.) and cabbage (Brassica oleracea capitata L.). Pak. J. Bot. 39:753-760.

Karlidag, H., A. Esitken, E. Yildirim, M.G. Donmez, and M. Turan. 2011. Effects of plant growth promoting bacteria on yield growth, leaf water content, membrane permeability, and ionic composition of strawberry under saline conditions. J. Plant Nutr. 34:34-45.

Katsumi, M. 1991. Physiological modes of brassinolide action in cucumber hypocotyls growth, p. 246-254. In: Cutler, H.G., T. Yokota, and G. Adam (eds.). Brassinosteroids chemistry, bioactivity and applications. ACS, Symp. Ser. 474. Am. Chem. Soc., Washington, DC

Khan, W., B. Prithiviraj, and D.L. Smith. 2003 Photosynthetic responses of corn and soybean to foliar application of salicylates. J. Plant Physiol. 160:485-492.

Kirst, G.O. 1989. Salinity tolerance of eukaryotic marine algae. Annu. Rev. Plant Physiol. Plant Mol. Biol. 40:21-53.

Mertens, D. 2005a. AOAC Official Method 922.02, p. 1-2. In: Horwitz, W. and G.W. Latimer (eds.). Plants preparation of laboratory sample. Official methods of analysis. 18th Ed. AOACInternational, Gaithersburg, MD.

Mertens, D. 2005b. AOAC Official Method 975.03., p. 3-4. In: Horwitz, W. and G.W. Latimer (eds.) Metal in plants and pet foods. Official methods of analysis. 18th Ed. AOAC-International, Gaithersburg, MD.

Misra, A.N., S.M. Sahl, M. Misra, P. Singh, T. Meera, N. Das, M. Har, and P. Sahu. 1997. Sodium chloride induced changes in leaf growth, and pigment and protein contents in two rice cultivars. Biol. Plant. 39:257-262.

Morillon, R., M. Catterou, R.S. Sangwan, B.S Sangwan, and J.P. Lassalles. 2001. Brassinolide may control aquaporin activities in Arabidopsis thaliana. Planta 212:199-204.

Nakajima, N., A. Shida, and S. Toyama. 1996. Effects of brassinosteroid on cell division and colony formation of chinese cabbage mesophyll protoplasts. Jpn. J. Crop. Sci. 65:114-118.

Neufeld, H., A.H. Chappelka, G.L. Somers, K.O. Burkey, A.W. Davison, and P. Finkelstein. 2006. Visible foliar injury caused by ozone alters the relationship between SPAD meter readings and chlorophyll concentrations in cut leaf coneflower. Photosynth. Res. 87:281-286.

Oh, M.H. and S.D. Clouse. 1998. Brassinolide affects the rate of cell division in isolated leaf protoplasts of Petunia hybrida. Plant Cell Rep. 17:921-924.

Parida, A.K. and A.B. Das. 2005. Salt tolerance and salinity effects on plants: A review. Ecotoxicol. Environ. Saf. 60:324-349.

Sakurai, A., T. Yokota, and S.D. Clouse. 1999. Brassinosteroids. Springer-Verlag, Tokyo, Japan. p. 253.

SAS Institute. 1985. SAS introductory guide. 3rd Ed. SAS Institute, Cary, NC.

Shahbaz, M. and M. Ashraf. 2007. Influence of exogenous application of brassinosteroid on growth and mineral nutrients of wheat (Triticum aestivum $\mathrm{L}$.) under saline conditions. Pak. J. Bot. 39:513-522.

Shahbaz, M., M. Ashraf, and H. Athar. 2008. Dose exogenous application of 24-epibrassinolide ameliorate salt induced growth inhibition in wheat (Triticum aestivum L.). Plant Growth Regulat. 55:51-64.

Shannon, M.C. 1997. Adaptation of plants to salinity. Adv. Agron. 60:75-120.

Shannon, M.C. and C.M. Grieve. 1999. Tolerance of vegetables to salinity. Sci. Hort. 78:5-38.

Shi, Q., Z. Bao, Z. Zhu, Q. Ying, and Q. Qian. 2006. Effects of different treatments of salicylic acid on heat tolerance, chlorophyll fluorescence, and antioxidant enzyme activity in seedlings of Cucumis sativus L. Plant Growth Regulat. 48:127-135.

Swamy, K.N. and S.S.R. Rao. 2009. Effect of 24Epibrassinolide on growth, photosynthesis and essential oil content of Pelargonium graveolens (L.). Herit. Russian J. Plant Physiol. 56:616-620.

Tarakcioglu, C. and A. Inal. 2002. Changes induced by salinity, demarcating specific ion ratio $(\mathrm{Na} / \mathrm{Cl})$ and osmolality in ion and proline accumulation, nitrate reductase activity, and growth performance of lettuce. J. Plant Nutr. 25:27-41.

Vardhini, B.V. and S.S.R. Rao. 1997. Effect of brassinosteroids on salinity induced growth inhibition of ground nut seedlings. Indian J. Plant Physiol. 2:156-157.

Wang, M., W. Jiang, and H. Yu. 2010. Effects of exogenous epibrassinolide on photosynthetic characteristics in tomato (Lycopersicon esculentum Mill) seedlings under weak light stress. J. Agr. Food Chem. 58:3642-3645.

Xia, X.J., Y.J. Wang, Y.H. Zhou, Y. Tao, W.H. Mao, K. Shi, T. Asami, Z. Chen, and J.Q. Yu. 2009. Reactive oxygen species are involved in brassinosteroid-induced stress tolerance in cucumber. Plant Physiol. 150:801-814.

Yildirim, E., M.F. Donmez, and M. Turan. 2008b. Use of bioinoculants in ameliorative effect on radish (Raphanus sativus L.) plants under salinity stress. J. Plant Nutr. 31:2059-2074.

Yildirim, E., H. Karlidag, and M. Turan. 2009. Mitigation of salt stress in strawberry by foliar $\mathrm{K}, \mathrm{Ca}$ and $\mathrm{Mg}$ nutrient supply. Plant Soil Environ. 55:213-221.

Yildirim, E., A.G. Taylor, and T.D. Spittler. 2006. Ameliorative effects of biological treatments on growth of squash plants under salt stress. Sci. Hort. 111:1-6.

Yildirim, E., M. Turan, and I. Guvenc. 2008a. Effect of foliar salicylic acid applications on growth, chlorophyll and mineral content of cucumber (Cucumis sativus L.) grown under salt stress. J. Plant Nutr. 31:593-612.

Yu, J.Q., L.F. Huang, W.H. Hu, Y.H. Zhou, W.H. Mao, S.F. Ye, and S. Nogues. 2004. A role for brassinosteroids in regulation of photosynthesis in Cucumis sativus. J. Expt. Bot. 55:1135-1143. 